\title{
Stakeholders' theory and its contribution to the sustainable development of a tourism destination
}

\author{
S. F. Queiroz \\ Pontifícia Universidade Católica de Minas Gerais, Brazil
}

\begin{abstract}
The forecast of continuous transformations in the world, and the analysis of their influence on the principles that guide the tourism development of a locality are essential to the efficient management of this sector. In this context, tourism destinations face the commitment of finding sustainable development models, since failure to reach this goal will probably result in an activity with few future perspectives. In particular in developing countries, resistance that prevents the implementation of management principles related to sustainability in tourism destinations can still be felt. The development models adopted in these places were, in many cases, inefficient and therefore did not bring social dignity to their residents. It is believed that the main mistakes of the managers of these receiving communities are related to the lack of stakeholder involvement and participation. The sustainability principle practices must be understood as an action centered on the mobilization capacity of the persons involved, in the motivation of their behavior and in the recognition of the importance of their opinion to the decision process. Up to the present, there have been few studies dedicated to a more detailed theoretical analysis about this issue applied to the sustainable tourism development of a locality. Thus, the conceptual milestones that may support the initiatives in this matter are still under discussion. This study proposes an evaluation of the sustainability concept applicability which is extended to the analysis of the stakeholder behavior and involvement. Therefore it is necessary, in the first place, to know the human relations that determine this process and the interests and goals that are part of them, since such initiative is a fundamental condition to design sustainable actions.
\end{abstract}

Keywords: tourism development, sustainability, stakeholders' theory, joint management, developing countries, democratic participation. 


\section{Introduction}

Among the most meaningful thoughts of the $20^{\text {th }}$ century is the discussion about the way the world population uses and explores the environmental resources of the planet. Based on this concern, the sustainable development becomes an obligatory concept for any activity.

There is a favorable scenario for studies portraying the possibility of a tourism development on which the positive effects may outnumber the negative ones. In the past years, this reality has led to some changes regarding the conception forms of activities related to this sector. At present, tourism focused solely on economical interests, which neglects social and environmental development, is seen as entirely inadequate for attaining benefits.

Therefore, the tourism sector starts its efforts to respond positively to this context, in an attempt to avoid the mistakes previously made and aiming at showing its responsible and preservationist side [1]. The adaptation of its management processes to conservation ideas, as well as the adoption of development models leading to sustainability have become a priority, since tourism depends on the surroundings where it is developed.

Since then, a considerable amount of discussion about the sustainable tourism has been carried out. The debate about tourism sustainability has become so common that one may consider this theme concluded. However, as for any scientific issue, its problems are never completely solved. Every day, the world dynamics generates new situations in need of solutions.

Another point to be considered in this context is the fact that a great part of people involved with tourism activities do not know the real essence of sustainability, whose content is theoretical, complex and hardly accessible.

As a consequence, up to the present, the concept of sustainability has not been transcended into a more pragmatic sphere. The results from the actions implemented so far have been very limited, in a way that no conclusions regarding the procedures capable of materializing this discussion into a more concrete reality have been drawn.

\section{Sustainable tourism development in developing countries}

It can be stated that the incapacity for concretization of a sustainable tourism management becomes more evident in the tourism destinations of the developing countries, since the beginning of many utilization processes of unexplored natural resources based on the false premise about sustainability can be identified in those countries.

In this sense, the actions developed are based on the conceptions of some authors who state that the essence of the sustainable tourism management lies on the development of certain tourism modalities compatible with the principles of sustainability [2]. This has motivated the growth of initiatives, in the developing countries, of activities such as ecotourism, green tourism, rural tourism, agro tourism, among others. However, this conviction can be extremely dangerous, 
mainly because more and more often the use of this argument in the commercialization of natural tourism destinations is noticed [3].

So, despite the lack of concrete studies, based on empirical researches, there is an assumption that independent trips are more sustainable than the tourism packages offered by travel agencies, that some destinations present smaller sustainability than the destinations where the ecotourism is practiced and in summary, that the small scale tourism is better than the mass tourism [4].

It is not right to operate in areas naturally attractive, which are mostly sensitive places, considering only the type of intervention used and without any concern about its way of development form. It must not be forgotten that as they are tourism modalities which keep a more intense and reciprocal contact with its natural, economical, human and cultural environment, they demand better preparation, planning and technique to assess its real role and its effects on the society.

Other theorists question the inherent sustainability of these tourism forms and warn about the impacts they can provoke $[5,6]$. The statement that certain tourism modalities spontaneously generate a sustainable tourism is wrong. As any type of activity, the implementation of this type of tourism originates, inevitably, impacts, either positive or negative [7].

However, it must not be forgotten that tourism itself is not harmful and that the mistake of many tourism destinations of the developing countries is related to the management models adopted [8]. The conquest of sustainability can and must be associated to all the tourism modalities, and in order to achieve this, proper planning and control are extremely necessary.

Nonetheless, in spite of such apparent and evident consequences, many are the managers who deny recognizing the impacts inherent to tourism and refuse to carry out any proposals for assessing the development of its activities. The lack of a responsible management has provoked some vulnerability in the destinations, and consequently, the resources upon which the tourism prosperity was based on are being degraded [9]. For this reason, in order for the receiving communities to move from the extractive development and achieve the real principles of the local development, instead of strictly economicist principles, those focused on the social development should be followed [10].

A persistent resistance still prevails in those countries preventing the development of means of management related to the sustainability. It is necessary to arouse a new consciousness which will lead to a reduction of the risks of the activities related to this sector.

Unless there is a general awareness of the responsibilities to which this process leads, the possibility of achieving progress concerning sustainability will be scarce. The sustainable tourism development implies in decision making, very often hard and mainly demanding long term view.

\section{A model of sustainable tourism management for developing countries}

It is a universal concept today, the fact that sustainability is multidimensional and demands a joint exploration of the aspects related to the environment, the 
economy, the society, the culture, and the politics, among many others. Thus, it is important for a tourism design to analyze how these multiple aspects behave, considering the particular characteristics of each destination. So, it is an assumption that the concept of sustainable tourism must be considered as a model to be adapted to the characteristics of each destination.

But, what determines the characteristics of a tourism destination? The answer to this question must take into account that such characteristics are defined by the quality of the social relations among the groups involved in the process of tourism development, and by the commitment these groups have to the present generations, as well as the future ones.

Basic infra-structure and services offered by a tourism destination can be considered ordinary components, when compared to the social and cultural manifestations of the groups involved, as they establish the real connections of the activity. This is the reason why some communities with similar attractions, very often, present very different tourism development.

This way, it is an assumption that an analysis focused on the people involved in the process is essential for the development of the sustainability concept, as the effects impacting the nature, the economical balance and mainly, the social balance are entirely conditioned by the several ways of human relationships and its potential. That is to say, all the impacts provoked by the tourism derive from the interactions among the agents involved in the process [11].

Thus, it is possible to state that the nature of the human relations is the primary factor fomenting a suitable understanding for the tourism process. Acknowledging this argument leads to the searching of new ethical references for sustainability based on fraternity, solidarity and social equality.

Although the authors conduct us into the tourism environmental and economical effects, the understanding of sustainability within these scopes depends on a humanistic analysis [4], as the awareness which will ensure sustainability of the natural surroundings depends entirely on the human being [12]. As it is defended by Hunziker quoted by Mazon [8], tourism constitutes an economical aspect only in a subsidiary way. The man is its real core.

Sustainability must be understood as a development process centered on people, and capable of mobilizing, motivating behavior and reinforcing values. Such principles, properly considered and analyzed, are able to promote considerable changes in the dominant models, causing improvement in the human and institutional relations.

As Krippendorff [13] comments, there is no necessity for distinct tourism activities, but for distinct human beings. It is necessary a change in the everyday context for tourism to follow a similar process.

\section{The integration of the stakeholders as a key-element on the process of sustainable tourism development}

As described by the WTO [9], sustainable tourism can be defined as a development model designed to attend: 1) The local population, as it aims at improving the life quality of those who reside in a tourism destination, dependent on it; 2) The tourist, promoting the excellence of the tourism experience; 3) The 
responsible agents for the tourism management, from the public or private sector, as profitability is the goal of those who invest on this activity.

These three groups of agents must be analyzed as inseparable elements in the reflection about tourism sustainability. Considering that being sustainable is to satisfy present and future necessities, it is conceivable the existence of different connotations for the concept, since the people involved in the tourism process have several interests and necessities, at the moment they get involved in the activity.

This way, a tourist and a hotel owner do not aim at the same goal when they meet and interact in a high-season period at a determined destination. The existing contact between these people features essentially antagonistic conditions. Therefore, the analysis of sustainability based on each one of these agents cannot be treated as a manipulation of the concept, as it is very often made explicit, but as an interpretation of the concept according to the focus of each agent.

It is possible to state then, that the basis of a sustainable tourism development is the conservation of this attractiveness for all the ones involved in this activity. The idea leads us into different lines, as it must satisfy the necessities of all the interested parts.

The trips become, this way, complex experiences upon which a series of agents intervene, with relations and interchange being established among them, due to the fragmentation and the transversality which characterizes these activities [14]. The association of these components results in a series of consequences, capable of solidifying, or not, the tourism development in a specific place.

The theory comprising this issue is called stakeholders' theory and was originally approached by Freeman [15]. To the author, a stakeholder, that is, a part interested in a determined process, can be defined as any group or individual affected by, directly or indirectly, the achieving of goals by an organization [15].

This way, any group or individual able to influence or be affected by any decision in the process to achieve the goals of an activity, and that, therefore, is truly interested in it, must be considered part of such activity, and thus, must be respected and deserving of consideration. That is why, an agent of the tourism sector must be described as the person, group or institution with power to generate an effect on the tourism activity, that's to say, with capacity to intervene, modify or influence the course of the sector [14].

On the other hand, it is worth mentioning that the distinct lines which represent the multiple parts interested in a tourism business must be led into a common goal. It is necessary then, to search for a consensus, which in the case of sustainability, is projected in the general idea of the continual aspect of the activity.

\section{Theoretical models for the stakeholders joint management of the tourism sector}

Jamal and Getz [16] defend the argument that tourism cooperation is a process of making joint decisions, among autonomous key-actors, who constitute an inter- 
organizational structure in the receiving community, to solve the problems related to the design and management from a sustainable scope. McIntosh et al [17] reinforce this premise and state that in order to work, the sustainable development must be converted into a normal way of thinking and acting conducted by everybody. Therefore, tourism cannot be an exclusive sector of some segments of the society and its responsibility must be delegated to all the ones involved.

Participative proposals, which include all the agents involved in the process, can allow the proper identification of their necessities, roles and, consequently, the relations which define the tourism of a locality.

The great challenge lies on the best way to implement them, taking into account the multiple interests affecting them. Its concretization does not depend exclusively on an analysis of what a sustainable tourism means to each agent. On the contrary, it is necessary the understanding of the commitment of all the parts to achieve the common goal, based on the ethical principles involving this theory.

Aiming at avoiding a delusive speech, promoting the participation of the involved parts and obtaining collective benefits are not considered simple and easily applicable tasks. However, it is necessary to think of a policy whose decisions related to tourism development are more and more democratic, leading to a systemic view of this reality based, above all, on concerns and proposals from everybody.

Sautter and Leisen [18] defend that tourism must be analyzed from a more functional and cooperativist focus, which defends the interests of all the parts involved or affected by this activity. Such parts must manage, together, this system. These forms of management constitute the suitable way for tourism development. The competition among the receiving agents cannot go on being the basis of the tourism system management, for its incapacity to conciliate the economical efficiency with what sustainability really means nowadays [19].

Zapata [14] explains that at the present moment, joint participation schemes are accepted and applied in processes of several activity areas in all modern societies around us. In spite of this, the author warns about the existence of predominant factors which differentiate and determine their unique importance in the tourism field: the enormous diversity and multiplicity of products and services forming its reality, to which a wide diversity of agents who offer them is added, of both public and private character.

Few scholars have developed a more detailed theoretical analysis about this matter in the tourism sector. Therefore, the conceptual milestones, which support the practical initiatives already developed, are still under development.

A lot of sustainable development initiatives were related to the favoritism to one part, in detriment of others. The discussions and studies about the social and cultural impacts caused by tourism, sometimes focusing on the receiving community, and other times, on the tourist, confirm this reality.

The adhesion of all agents is indispensable in order to have an activity which features as a principle, the satisfaction of present and future necessities. As stated by Iniesta [20], sustainable tourism must be understood as an ideal towards 
which, one must be guided, but from different starting bases, including those sometimes considered impossible.

\section{Conclusion}

Taking into account Freeman's stakeholders' theory [15], an efficient tourism management which assesses the necessities of the different groups interested should comprise three basic steps: 1) The identification of each group and its perceived interest; 2) The necessary processes to manage the relations produced by the interested parts; and, 3) The joint management of the transactions and agreements among the groups interested.

The proposed point is a reassessment of the applicability of the sustainability concept, which can be extended to the analysis of the interested agents. The sustainable tourism development must be understood as a wider and open system which considers that each part influences the others. So, in first place, it is necessary to know the relations established by these agents, for only this way it is possible to obtain the basic tools for the design of sustainable actions.

On the other hand, it is admitted that, even with the establishment of the basic guidelines, yet, it will not be possible to quantify the preservation level sufficient for the achievement of the tourist sustainability along the generations. It will be a challenge living with the inevitable doubt presented when we refer to the necessities and values of the future generations.

However, thinking of today's balance may be the key for the achievement of tomorrow's balance, since by working out the inequalities suffered by the present generations, we will be formatting respectful individuals, who think of the collective and the development of values, which constitute a legacy for the ones to come.

\section{References}

[1] Cooper, C., Fletcher, J., Gilbert, D. \& Wanhill, S., Tourism: principles and practice, Addison Wesley Longman Publishing: New York, 1993.

[2] Fullana, P. \& Ayuso, S., Turismo Sostenible, Rubes Editorial: Barcelona, 2002.

[3] Ávila Bercial, R., Introducción al concepto de desarrollo turístico sustentable. Turismo Sostenible, ed. R. Ávila Bercial, Iepala Editorial: Madrid, 2002.

[4] Swarbrooke, J., Sustainable Tourism Management, CABI Publishing: Wallingford, 1998.

[5] Butler, R., Alternative tourism: the thin edge of the wedge. Tourism Alternatives: potentials and problems in the development of tourism, eds. V. Smith \& W. R. Eadington, John Wiley \& Sons: Chichester, 1994.

[6] Mowforth, M. \& Munt, I., Tourism and Sustainability: new tourism in the third world, Routledge: London, 1998. 
[7] Crosby, A. \& Moreda, A., Elementos Básicos Para un Turismo Sostenible en las Áreas Naturales, Centro Europeo de Formación Ambiental y Turística (CEFAT): Madrid, 1996.

[8] Mazón, T., Sociología del Turismo, Centro de Estudios Ramón Areces: Madrid, 2001.

[9] World Tourism Organization (WTO), Introducción al Turismo, Organización Mundial del Turismo: Madrid, 1998.

[10] Rubio Gil, A., (Coord.). Sociología del Turismo, Ed. Ariel: Barcelona, 2003.

[11] Mathieson, A. \& Wall, G., Tourism, Economic, Phisical and Social Impacts, Longman Group Limited: New York, 1982.

[12] Krippendorff, J., The Holiday Makers: understanding the impact of leisure and travel, Heinemann: London, 1987.

[13] Krippendorff, J., Sociologia do Turismo: para uma nova compreensão do lazer e das viagens, Civilização Brasileira: Rio de Janeiro, 1989.

[14] Zapata, M. J., Los agentes turísticos: una aproximación desde la sociología y la ciencia política. Sociología del Turismo, ed. A. Rubio Gil, Ariel Turismo: Barcelona, 2003.

[15] Freeman, E., Strategic Management: a stakeholder approach, Pitman Publishers: Boston, 1984.

[16] Jamal, T. B. \& Getz, D., Collaboration theory and community tourism planning. Annals Tourism Research, (22), pp. 186-204, 1985.

[17] Mcintosh, R. W., Goeldner, C. R. \& Ritchie, J. R. B., Turismo: planeación, administración y perspectivas, Editorial Limusa: México, 2000.

[18] Sautter, E. \& Leisen, B., La gestión de las partes interesadas. Un modelo de planificación turística. Annals of Tourism Research en Español, 1 (1), pp. 101-119, 1999.

[19] Brunet, I. \& Belzunegui, A., Los límites del turismo de masas: necesidad de una planificación sostenible para el desarrollo turístico. El Turismo en la Sociedad Contemporánea: diversificación, competitividad y desarrollo, eds. M. Latiesa \& A. Álvarez Sousa, A., Proyecto Sur: Granada, 2000.

[20] Iniesta, A., La aplicación del concepto de turismo sostenible en los países desarrollados. Turismo Sostenible, ed. R. Ávila Bercial, Iepala Editorial: Madrid, 2002. 